\title{
Aging of Bone Density in the Second Metacarpal
}

\author{
By \\ Kunihiko KIMURA \\ Department of Anatomy, National Defense Medical College, Tokorozawa, Saitama 359, Japan \\ - Received for Publication, August 2, $1991-$
}

Key Words: Bone density, Aging, Sex differences, Second metacarpal

\begin{abstract}
Summary: Bone weight, bone and cortical areas, and apparent and true bone densities (W/BV and W/CV) were measured on the second metacarpals of 114 male and 114 female Japanese, aged 30 to 98 years. Measurements were taken from midshaft cross-sections $2 \mathrm{~mm}$ thick, using an electron balance and an image analyzing system. The mean values of these variables were greater in men than in women at all ages. Bone area stayed almost unchanged regardless of age. Bone weight and cortical area decreased linearly with advancing age. The respective rates of decrease per decade observed for the these variables were $3.1 \%$ and $2.9 \%$ in men and $5.5 \%$ and $4.8 \%$ in women. Apparent bone density decreased gradually with age after the fourth decade in women. While, in men, it stayed almost unchanged or increased slightly until the fifth decade and then, decreased gradually with age. The rate of decrease per decade was accelerated after the fifth decade in women and after the sixth in men, being $10.3 \%$ and $8.1 \%$ in each gender, respectively. The mean loss of bone was about twice as great in women as in men. In women, significant differences $(p<0.01)$ were found in these variables after the seventh decade compared with the preceding age group. However, true bone density (W/CV) stayed almost unchanged regardless of age, being about 2.0 in men and about 1.9 in women. Osteoporosis could be primarily a manifestation of normal aging, including the postmenopausal estrogen deficiency in women, regardless of gender or race.
\end{abstract}

Currently, bone density is evaluated by various methods. As early as 1931, a series of 100 American white male skeletons ranging in age from 19 to 78 years was weighed by Ingalls (1931), who found that bone gives very definite evidence of age. Density (dry weight/volume) and percentage ash weight (ash weight/bone weight) of bones in adults were examined by Trotter and her colleagues in Euroand Afro-Americans (Trotter, 1954; Trotter et al., 1955, 1958, 1959, 1960, 1962; Broman et al., 1958). Trotter and her colleagues found that the density is higher in long limb bones and ribs than in vertebrae, in Afro-Americans than in Euro-Americans, and in men than in women. In addition, according to them, the density of bones decreases with age at approximately the same rate, but the percentage ash weight is not affected by age, regardless of race or gender.

Atkinson and co-workers (1962) examined the femoral bone density using a small pyknometer in 91 cadavers aged 20 to 89 years, and reported that there is no change in the degree of mineralization of the cortical bone with age. From a subsequent study using femurs of 80 cadavers aged 0 to 99 years, Atkinson and Weatherell (1967) concluded that the bone density is greatest from 30 to 50 years, after which age the density falls. Lindahl and Lindgren (1967) studied bone density in humeri and femurs of 64 cadavers aged 15 to 89 years, and concluded that the bone density increases significantly with age in men more than 50 years old, but that in women there is a slight but non-significant reduction in the density with age. Recently, studying the humeral cortex of 89 cadavers, Laval-Jeantet and colleagues (1983) found that apparent mineral density is linked to porosity and decreases markedly with age in women, but that a true mineral density does not vary significantly with age in either gender.

The present paper examines age and sex differences of apparent and true densities of the second metacarpal. According to Aitken and associates (1974), the metacarpal provides useful information on whole bone densities at other sites through the skeleton. In a previous paper (Kimura, 1990 ${ }^{1}$ ), it has been suggested that the metacarpal tends to be slightly greater in size in the right hand than in the left, but that it does not show any side-related differences in density. Thus, in the present paper, the description is limited to the right metacarpal.

\section{Material and Methods}

The second metacarpals of both hands were obtained from 228 Japanese cadavers during dissection 
by students between 1980 and 1991 . The specimens comprise 114 men aged 32 to 92 years $(x=62.5$ yrs., $\mathrm{SD}=14.81)$ and 114 women aged 30 to 98 years $(x=73.6 y r s ., S D=13.52)$. According to their death certificate, those individuals who had died of diseases involving bone loss were excluded as far as possible from the present study.

After removal of the soft tissues from the bone, a section greater than $2 \mathrm{~mm}$ thick was cut out at midshaft, perpendicular to the longitudinal axis, using a low-speed diamond-bladed circular saw (Buehler Isomet, U.S.A.). The section was ground down to $2 \mathrm{~mm}$ thickness using fine waterproof sandpaper. Subsequently, the section was immersed in warm water overnight with Protease A and P (Amano, Japan), washed with distilled water for 2 hours using a transonic irrigator (ELMA T780, Germany), and air-dried for over 24 hours. Finally, the section was radiographed with an anode-film distance of $76 \mathrm{~cm}$ in the proximodistal projection, using a standard radiographic technique $(45 \mathrm{kV}, 3.0 \mathrm{mAs}$ and $120 \mathrm{sec})$ with the Softex-C-MS system (Softex, Japan).
The section was weighed with an electron balance (Wg) with accuracy to $0.1 \mathrm{mg}$ (Sartorius Analytic A200S, Germany). On radiographs of the section, total bone and medullary areas (BA and $\mathrm{MA} \mathrm{mm}^{2}$ ) were measured with an image analyzing system, Spicca-II (Nippon Avionics, Japan), by tracing manually subperiosteal and smooth endosteal boundaries. Cortical area $(\mathrm{CA}=\mathrm{BA}-\mathrm{MA})$ was calculated from them. BV and $\mathrm{CV}$ were calculated by multiplying BA and CA by $2 \mathrm{~mm}$ thickness. Apparent and true bone densities of the section were calculated by dividing the weight $(\mathrm{Wg})$ by the bone and cortical volumes (BV and $\mathrm{CV} \mathrm{cm}{ }^{3}$ ). All the data were statistically analyzed and tested using the SAS.

\section{Results}

Table 1 gives means and standard deviations for $\mathrm{W}, \mathrm{BA}, \mathrm{CA}, \mathrm{W} / \mathrm{BV}$ and $\mathrm{W} / \mathrm{CV}$ in five age groups; $30-49,50-59,60-69,70-79$ and $80-99$ years. The mean values of these variables were significantly

Table 1. Means and standard deviations of the parameters of the second metacarpals in each age group.

\begin{tabular}{|c|c|c|c|c|c|c|c|c|}
\hline & & & Males & & & Female & & \\
\hline & Age & $\mathbf{n}$ & m & $\mathrm{SD}$ & $\mathbf{n}$ & m & SD & Sex diff. \\
\hline Bone weight & $30-49$ & 26 & 0.17 & 0.1527 & 6 & 0.13 & 0.0247 & $* *$ \\
\hline$=\mathrm{W}(\mathrm{g})$ & $50-59$ & 30 & 0.16 & 0.0233 & 12 & 0.12 & 0.0314 & $* *$ \\
\hline & $60-69$ & 21 & 0.16 & 0.0245 & 21 & 0.11 & 0.0181 & $* *$ \\
\hline & $70-79$ & 18 & 0.15 & 0.0239 & 40 & 0.10 & 0.0188 & $* *$ \\
\hline & $80-99$ & 19 & 0.14 & 0.0294 & 35 & 0.08 & 0.0188 & $* *$ \\
\hline Bone area & $30-49$ & 26 & 58.07 & 6.4704 & 6 & 48.71 & 5.7239 & $* *$ \\
\hline$=\mathrm{BA}\left(\mathrm{mm}^{2}\right)$ & $50-59$ & 30 & 54.93 & 7.4799 & 12 & 44.62 & 7.6008 & $* *$ \\
\hline & $60-69$ & 21 & 56.36 & 8.0478 & 21 & 45.80 & 4.9140 & $* *$ \\
\hline & $70-79$ & 18 & 55.36 & 5.1751 & 40 & 45.60 & 5.9054 & $* *$ \\
\hline & $80-99$ & 19 & 56.86 & 5.9127 & 35 & 45.83 & 4.6748 & $* *$ \\
\hline Cortical area & $30-49$ & 26 & 41.25 & 4.3959 & 6 & 32.59 & 6.0550 & $* *$ \\
\hline$=\mathrm{CA}\left(\mathrm{mm}^{2}\right)$ & $50-59$ & 30 & 39.31 & 5.7534 & 12 & 29.76 & 7.0356 & $* *$ \\
\hline & $60-69$ & 21 & 37.88 & 6.7583 & 21 & 29.25 & 5.8651 & $* *$ \\
\hline & $70-79$ & 18 & 37.49 & 5.8405 & 40 & 25.74 & 5.1702 & $* *$ \\
\hline & $80-99$ & 19 & 34.31 & 7.9780 & 35 & 21.87 & 5.9325 & $* *$ \\
\hline Apparent & $30-49$ & 26 & 1.47 & 0.1739 & 6 & 1.38 & 0.2658 & - \\
\hline Bone Density & $50-59$ & 30 & 1.46 & 0.1589 & 12 & 1.30 & 0.2833 & - \\
\hline$=\mathrm{W} / \mathrm{BV}$ & $60-69$ & 21 & 1.41 & 0.1442 & 21 & 1.26 & 0.1636 & $* *$ \\
\hline$\left(\mathrm{g} / \mathrm{cm}^{3}\right)$ & $70-79$ & 18 & 1.36 & 0.1893 & 40 & 1.06 & 0.1867 & $* *$ \\
\hline & $80-99$ & 19 & 1.20 & 0.2060 & 35 & 0.89 & 0.1890 & $* *$ \\
\hline True Bone & $30-49$ & 26 & 2.06 & 0.0848 & 6 & 2.05 & 0.1293 & - \\
\hline Density & $50-59$ & 30 & 2.03 & 0.1082 & 12 & 1.94 & 0.1807 & - \\
\hline$=\mathrm{W} / \mathrm{CV}$ & $60-69$ & 21 & 2.08 & 0.1108 & 21 & 1.99 & 0.1805 & $*$ \\
\hline$\left(\mathrm{g} / \mathrm{cm}^{3}\right)$ & $70-79$ & 18 & 2.01 & 0.1222 & 40 & 1.88 & 0.2191 & $* *$ \\
\hline & $80-99$ & 19 & 2.01 & 0.1485 & 35 & 1.90 & 0.2639 & - \\
\hline
\end{tabular}

Note: ${ }^{*}$ and ${ }^{* *}$, significant sex differences at $\mathrm{P}<0.05$ and 0.01 . Values in blod letter, significantly lesser than those in the preceding age group at $\mathrm{P}<0.01$. 
greater in men than in women in almost all age groups. Exceptions included the $\mathrm{W} / \mathrm{BV}$ in the $30-49$ and $50-59$ years groups and the W/CV in the 30-49, 50-59 and 80-99 years groups. The mean values of $\mathrm{W}, \mathrm{CA}$ and $\mathrm{W} / \mathrm{BV}$ were lower for each age group compared with the preceding age group in both genders; significantly for all three variables after the seventh decade in women $(p<0.01)$ and only for $\mathrm{W} / \mathrm{BV}$ after the eighth decade in men $(\mathrm{p}<0.05)$. While the mean values of $\mathrm{BA}$ and $\mathrm{W} / \mathrm{CV}$ were almost the same in each age group in both genders.

Plate 1 illustrates regression relationships of each variable to age in this series. Table 2 provides regression equations, standard errors (SE) and coefficients of determination $\left(r^{2}\right)$ of each variable $(y)$ with age $(x)$ for each gender separately. A significant linear regression was found with age in $\mathrm{W}, \mathrm{CA}$ and $\mathrm{W} / \mathrm{BV}$ at $\mathrm{p}<0.01$ in each gender. In addition, a somewhat better quadratic regression was found only for W/BV with age $(\mathrm{p}<0.01)$. As for the regression with age, significant sex differences were found for $\mathrm{W}$ and $\mathrm{BA}$ in only the intersection $(\mathrm{p}<0.01)$ and for $\mathrm{W} / \mathrm{BV}$ in both coefficient $(\mathrm{p}<0.01)$ and intersection $(\mathrm{p}<0.05)$. W, CA and $\mathrm{W} / \mathrm{BV}$ decreased gradually with advancing age, whereas $\mathrm{BV}$ and $\mathrm{W} /$ $C A$ remained almost unchanged regardless of age, in both genders.

\section{Discussion}

In this study, the bone weight and the bone and cortical areas were significantly greater in men than in women at all ages. The mean value was also signi- ficantly greater in men than in women for the apparent bone density after the sixth decade and for the true bone density in the $60-69$ and $70-79$ years groups. As for the sexual differences in bone mass and density, the same conclusion emerged from a microdensitometric study of bone mass and density undertaken on the same series (Kimura et al., 1989). This is also consistent with other studies of density and percentage ash weight of bones in Euro- and Afro-Americans (Trotter, 1954; Trotter et al., 1955, 1958, 1959, 1960, 1962; Broman et al., 1958).

Bone area stayed unchanged regardless of age in this series, approximately being $56 \mathrm{~mm}^{2}$ in men and $46 \mathrm{~mm}^{2}$ in women. The same fact has been found for bone length and width in the same series, being about $66 \mathrm{~mm}$ and $8 \mathrm{~mm}$ in men and about $62 \mathrm{~mm}$ and $7 \mathrm{~mm}$ in women in each variable (Kimura et al., 1989). Based on femoral radiographs of 2,030 women, Smith and Walker (1964) first pointed out that periosteal diameter increases even after fifty years of age. After studying tetracycline labels deposited in vivo, Epker and Frost (1966) found that in human ribs there can be continued apposition of periosteal bone after 20 years of age, which decreases in amount with advancing age but is still present in the seventh decade. Garn et al. (1967) produced similar findings for the second metacarpal in longitudinal data on 113 men and women. Further, based on the cross-sectional data from eight populations, Garn and associates (1968) suggested that adult subperiosteal gain continues from the third through the ninth decades. On the other hand, Trotter et al. (1968) did not support such a hypothesis. Recently, from the longitudinal study in men, as well as in the crosssectional

Table 2. Regression equations, standard errors and coefficients of determination of each parameter of the second metacarpal (y) with age ( $x$ ) in 114 males (32-92 years) and 114 females (30-98 years)

\begin{tabular}{|c|c|c|c|c|c|c|c|}
\hline & \multirow[b]{2}{*}{ Sex } & \multirow[b]{2}{*}{ Regression equation } & \multirow[b]{2}{*}{ SE } & \multirow[b]{2}{*}{$r^{2}$} & \multirow[b]{2}{*}{ Lineality } & \multicolumn{2}{|c|}{ Sex diff. } \\
\hline & & & & & & coef. & int. \\
\hline W & $\delta$ & $y=0.1997-0.0007 x$ & 0.0231 & 0.1676 & $* *$ & & \\
\hline (g) & q & $y=0.1790-0.0011 x$ & 0.0205 & 0.3403 & $* *$ & - & $* *$ \\
\hline \multirow{2}{*}{$\begin{array}{l}\text { BA } \\
\left(\mathrm{mm}^{2}\right)\end{array}$} & $\delta$ & $y=57.0097-0.0113 x$ & 6.8180 & 0.0006 & - & & \\
\hline & $q$ & $y=45.8991-0.0018 x$ & 5.5115 & 0.0000 & - & - & ** \\
\hline \multirow{2}{*}{$\begin{array}{l}\mathrm{CA} \\
\left(\mathrm{mm}^{2}\right)\end{array}$} & $\delta$ & $y=47.8402-0.1515 x$ & 6.0404 & 0.1222 & ** & & \\
\hline & $q$ & $y=42.3433-0.2222 x$ & 5.8905 & 0.2079 & ** & - & - \\
\hline \multirow{4}{*}{$\begin{array}{l}\mathrm{W} / \mathrm{BV} \\
\left(\mathrm{g} / \mathrm{mm}^{3}\right)\end{array}$} & o & $y=1.1119+0.0159 x-0.0002 x^{2}$ & 0.1699 & 0.2552 & $* *$ & & \\
\hline & & $y=1.7777-0.0062 x$ & 0.1733 & 0.2183 & $* *$ & & \\
\hline & $q$ & $y=1.2818+0.0088 x-0.0002 x^{2}$ & 0.1974 & 0.4123 & ** & $* *$ & * \\
\hline & & $y=1.9533-0.0118 x$ & 0.2004 & 0.3887 & $* *$ & $* *$ & * \\
\hline \multirow{2}{*}{$\begin{array}{l}\text { W/CV } \\
\left(\mathrm{g} / \mathrm{mm}^{3}\right)\end{array}$} & $\delta$ & $y=2.0949-0.0008 x$ & 0.1160 & 0.0116 & - & & \\
\hline & @ & $y=2.1756-0.0034 x$ & 0.2186 & 0.0437 & - & - & - \\
\hline
\end{tabular}

Note: ${ }^{*}$ and ${ }^{* *}$, significant levels at $\mathrm{P}<0.05$ and 0.01 . 
data, Fox et al. (1986) concluded that the width and length of the second metacarpal do not change significantly with age after adulthood is reached.

The cortical bone mass (W and CA) and apparent bone density decreased gradually with advancing age. A significant linear regression was found between each variable and age $(p<0.01)$ after the third decade in both genders. Bone loss proceeded for each variable at a rate per decade of $3.1 \%, 2.9 \%$ and $3.1 \%$ in men and $5.5 \%, 4.8 \%$ and $5.5 \%$ in women, respectively. In addition, from a significant quadratic regression the apparent bone density with age $(p<0.01)$, the following fact was noted: The apparent bone density decreases gradually with age after the fourth decade in women, while it stays almost unchanged or slightly increases until the fifth decade at least and then decreases gradually with age in men. An accelerated rate of bone loss is observed after the fifth decade in women and after the sixth in men, being $10.3 \%$ and $8.1 \%$ per decade in each gender, respectively. In general, the rate of bone loss is about twice as great in women as in men. Compared with the preceding age group, significant differences were found in the mean values for these parameters after the seventh decade in women $(p<0.01)$ and only for W/BV at the eighth decade in men $(\mathrm{p}<0.05)$.

Cortical bone mass or density begins to decrease soon after maturity is reached in both genders (Odland et al., 1958; Frost, 1966; Garn et al., 1969; Dequeker, 1972). Newton-John and Morgan (1970) reviewed the osteometric or radiogrametric studies and concluded that loss of cortex begins at the age of 40-45 years in women and 50-65 years in men. Thereafter, Mazess (1982) reviewed the absorptiometric studies and pointed out that, in compact bone, aging decreases of $3 \%$ per decade begin at about 40 years in both genders and continue, but in women, an additional loss occurs after menopause, bringing their total rate of decrease to $9 \%$ per decade between ages 45 and 75 . Total body calcium is lost at a slow rate $(0.37 \%$ /year) beginning in the fourth decade and a moe rapid postmenopausal rate $(1.1 \%$ / year) is superimposed on the slower rate, beginning in the sixth decade (Cohn et al., 1976 ${ }^{1}, 1976^{2}$ ). An accelerated rate of bone loss is observed between 50 and 57 years in women and after 68 years in men (Trouerbach et al., 1987, 1988). According to a longitudinal study by Nordin and Polly (1987), the rate of bone loss is maximal in the first 10 years after the menopause and then progressively diminished. Following menopause, the bone loss amounts to about $8-10 \%$ per decade in North Americans and Southern Europeans (Meema et al., 1965, 1978; Garn et al., 1967; Dequeker, 1972; Mazess and Cameron, 1974; Donath et al., 1974; Smith et al.,
1975) and perhaps as much as $10-15 \%$ per decade in Northern Europeans (Newton-John and Morgan, 1970; Christiansen et al., 1975; Lindsay et al., 1976; Horsman et al., 1977).

The results obtained from the present study is consistent with these studies. Thus, bone loss proceed at almost the same rate with age after the fifth decade in women and the sixth in men regardless of race. It is a general aging phenomenon, regardless of gender or race (Meema, 1963; Frost, 1966; Newton-John and Morgan, 1970; Atkinson and Woodhead, 1973; Garn, 1975; Ericksen, 1976), and also must be due to some additional effects on the female skeleton, most likely the postmenopausal estrogen deficiency (Thomsen et al., 1986). In addition, Fox et al. (1986) suggested that no cohort or secular effects are found to influence this process.

In this study, the true bone density stays almost unchanged regardless of age, approximately being 2.0 in men and 1.9 in women, or decreases slightly with advancing age in both genders. The same fact was observed in the percentage ash weight (Trotter and Peterson, 1962), true mineral density (LavalJeantet et al., 1983) and mean peak height in MD pattern of the midshaft cross-section (Kimura, 1990²) of human bones. In a study by neutron activation analysis (Cohn et al., 1976 ${ }^{2}$ ), the ratio of total body phosphorus/total body calcium was also constant with age. These and the present study support the finding that the mineral composition of bone does not change significantly with age (Follis, 1952; Woodard, 1962; Morisaki et al., 1970; Dequeker, 1972). According to histological studies (Jowsey, 1960; Thompson, 1980), summed Haversian canal area values and Haversian canal numbers increase significantly with age at $p<0.05$. Laval-Jeantet and his colleagues (1983) observed no significant differences in porosity (the proportion of the cortical bone are occupied by vascular and resorption cavities) between men and women. The slight loss of $\mathrm{W} / \mathrm{CV}$ with age observed in the present study may be due to such age changes of Haversian canals and a relative increase of cancellous-type bone to the bone weight, or to the secular effect.

Currently, the term osteoporosis remains widely used to indicate a reduction in the volume of bony tissue relative to whole bone volume (Nordin, 1987). It is essentially the loss of cancellous elements and of cortical bone at the endosteal surface (Epker and Frost, 1969) and primarily a manifestation of normal aging, including the postmenopausal estrogen deficiency in women, regardless of gender or race. While, true bone density does not change significantly with age. 


\section{Literature cited}

1) Aitken, J.M., Smith, C,B., Horton, P.W., Clark, D.L., Boyd, J.F. and Smith, D.A.: The interrelationship between bone mineral at different skeletal sites in male and female cadavera. J. Bone Joint Surg., 56B: 370-375, 1974.

2) Atkinson, P.J., Weatherell, J.A. and Weidmann, S.M.: Changes in density of the human femoral cortex with age. J. Bone Joint Surg., 44B: 496-502, 1962.

3) Atkinson, P.J. and Weatherell, J.A.: Variation in the density of the femoral diaphysis with age. J. Bone Joint. Surg., 49B: 781-788, 1967.

4) Atkinson, P.J. and Woodhead, C.: The development of osteoporosis. Clin. Orthop., 90: 217-228, 1973.

5) Broman, G.E., Trotter, M. and Peterson, R.R.: The density of selected bones of the human skeleton. Am. J. Phys. Anthropol., 16: 197-212, 1958.

6) Cohn, S.H., Vaswani, A.N., Zanzi, I., Aloia, H.F., Roginsky, M.S. and Ellis, K.J.: Changes in body chemical composition with age measured by total body neutron activation. Metab., 25: 85-95, 1976 ${ }^{1}$.

7) Cohn, S.H., Zanzi, I., Vaswani, A.N., Wallach, S., Aloia, J.F. and Ellis, K.J.: Quantitation of the degree of osteoporosis by measure of total body calcium. Calcif. Tiss. Res., 21: $375-379,1976^{2}$

8) Christiansen, C., Rødbro, P. and Jensen, H.: Bone mineral content in the forearm measured by photon absorptiometry. Scand. J. Clin. Lab. Invest., 35: 720-722, 1975.

9) Dequeker, J.V.: Bone Loss in Normal and Pathological Conditions, pp 214. Leuven Univ Press, Leuven, 1972.

10) Donath, A., Indermuhle, $P$. and Baud, R.: Mineralmometrie osseuse mesuree par l'absorption des photons d'une source $\mathrm{d}^{125}$ I. Radiol. Clin. Biol., 43: 393-400, 1974.

11) Epker, B.N. and Frost, H.M.: Periosteal appositional bone growth from age two to age seventy in man. A tetracycline evaluation. Anat. Rec., 154: 573-577, 1966.

12) Epker, B.N. and Frost, H.M.: A histological study of remodeling at the periosteal, haversian canal, cortical endosteal, and trabecular endosteal surfaces in human rib. Anat. Rec., 152: 129-136, 1969.

13) Ericksen, M.F.: Cortical bone loss with age in three native American populations. Am. J. Phys. Anthropol., 45: 443-452, 1976.

14) Follis, R.H., Jr: The inorganic composition of the human rib with and without marrow elements. J. Biol. Chem., 194: 223-226, 1952.

15) Fox, K.M., Tobin, T.D. and Plato, C.C.: Longitudinal study of bone loss in the second metacarpal. Calcif. Tiss. Int., 39: 218-225, 1986.

16) Frost, H.M.: Bone dynamics in osteoporosis and osteomalacia. Charles C Thomas, Springfield, pp 74-78, 1966.

17) Garn, S.M.: Bone-loss and aging, pp 39-57. In: Physiology and Pathology of Human Aging. Academic Press Inc., New York, San Francisco and London, 1975.

18) Garn, S.M., Guzman, M.A. and Wagner, B.: Subperiosteal gain and endosteal loss in protein-calorie malnutrition. Am. J. Phys. Anthropol., 30: 153-156, 1969.

19) Garn, S.M., Rohmann, C.G., Wagner, B. and Ascoli, W.: Continuing bone growth through life: a general phenomenon. Am. J. Phys. Anthropol., 26: 313-317, 1967.

20) Garn, S.M., Wagner, B., Rohmann, C.G. and Ascoli, W.: Further evidence for continuing bone expansion. Am. J. Phys. Anthropol., 28: 219-222, 1968.

21) Horsman, A., Simpson, M., Kirby, P.A. and Nordin, B.E.C.: Non-lincar bone loss in oophorectomized women. Br. J. Radiol., 50: 504-507, 1977.

22) Ingalls, N.W.: Observations on bone weights. Am. J. Anat.,
48: 45-98, 1931

23) Jowsey, J.: Age changes in human bone. Clin. Orthop. Relat. Res., 17: 210-217, 1970.

24) Kimura, K.: Bilateral asymmetry of cross-sectional radiogrametric and microdensitometric measurements in the second metacarpal. Okajimas Folia anat. jpn., 67: 39-45, 1990'1.

25) Kimura, K:: Age and sex differences in bone density of the second metacarpal in its midshaft cross-section. Annulus of Human Biology, 17: 399-406, 1990².

26) Kimura, K., Konishi, M. and Kimura, K.: Side, age and sex-related differences in microdensitometric measurements of the second metacarpal. Jpn. J. Hum. Post., 9: 67-80, 1989.

27) Laval-Jeantet, A.-M., Bergot, C., Carroll, R. and GarciaSchaefer, F.: Cortical bone senescence and mineral bone density of the humerus. Calcif. Tiss. Int., 35: 268-272, 1983.

28) Lindahl, O. and Lindgren, A.G.H.: Cortical bone in man. 1. Variation of the amount and density with age and sex. Acta orthop. Scand., 38: 133-140, 1967.

29) Mazess, R.B.: On aging bone loss. Clin. Orthop. Related Research, 165: 239-252, 1982.

30) Mazess, R.B. and Cameron, J.R.: Bone mineral content in normal US whites, pp 228-238. In: Mazess, R.B. (ed.), International Conference n Bone Mineral Measurement, Dhew Publ, Washington DC, 1974.

31) Meema, H.E.: Cortical bone atrophy and osteoporosis as a manifestation of aging. Am. J. Roentgenol., 89: 1287$1295,1963$.

32) Meema, H.E., Bunker, M.L. and Meema, S.: Loss of compact bone due to menopause. Obst. Gynecol., 26: 333-343, 1965.

33) Meema, H.E. and Meema, S.: Compact bone mineral density of the normal human radius. Acta Radiol. Oncol., 17: $342-352,1978$.

34) Morisaki, N., Takayanagi, K., Sugawara, Y., Ueda, R. and Matsumura, T.: Age differences of bone composition. Bone Metab., 3: 61-63, 1970. (in Japanese)

35) Newton-John, H.F. and Morgan, D.B.: The loss of bone with age, osteoporosis, and fractures. Clin. Orthop., 71: 229-252, 1970.

36) Nordin, B.E.C.: The definition and diagnosis of osteoporosis. Calcif. Tiss. Int., 40: 57-58, 1987.

37) Nordin, B.E.C. and Polly, K.J.: Metabolic consequences of the menopause. A cross-sectional, longitudinal, and intervention study on 557 normal postmenopausal women. Calcif. Tiss., 44: S1-S54, 1987.

38) Odland, L.M., Warnick, K.P. and Esselbaugh, N.C.: Bone density, pp 35. In Morgan, A.F. (ed.): Cooperative Nutritional Status Studies in Western Region. Montan Agricultural Experiment Station, Bulletin 534, 1958.

39) Smith, D.M., Khariri, M.R.A. and Jonston, C.C., Jr.: The loss of bone mineral with aging and its relationship to risk of fracture. J. Clin. Invest., 56: 311-318, 1975.

40) Smith, R.W. and Walker, R.R.: Femoral expansion in aging women: Implications for osteoporosis and fractures. Science, 145: 156-157, 1964.

41) Thompson, D.D.: Age changes in bone mineralization, cortical thickness, and Haversian canal area. Calcif. Tiss. Int., 31: 5-11, 1980.

42) Thomsen, K., Gotfredsen. A. and Christiansen, C.: Is postmenopausal bone loss an age-related phenomenon? Calcif. Tiss. Int., 39: 123-127, 1986.

43) Trotter, M.: A preliminary study of estimation of weight of the skeleton. Am. J. Phys. Anthropol., 12: 537-552, 1954.

44) Trotter, M., Broman, G.E. and Peterson, R.R.: The density of humeri of American Whites and Negroes. The Leech, 28: 139-143, 1958.

45) Trotter, M., Broman, G.E. and Peterson, R.R.: Densits 
of cervical vertebrae and comparison with densities of other bones. Am. J. Phys. Anthropol., 17: 19-25, 1959.

46) Trotter, M., Broman, G.E. and Peterson, R.R.: Densities of bones of White and Negro skeleton. J. Bone Joint. Surg., 42A: 50-58, 1960 .

47) Trotter, M. and Peterson, R.R.: Ash weight of human skeletons in per cent of their dry fat-free weight. Anat. Rec., 123: 341-358, 1955.

48) Trotter, M. and Peterson, R.R.: The relationship of ash weight and organic weight of human skeletons. J. Bone Joint. Surg., 44A: 669-681, 1962.

49) Trotter, M., Peterson, R.R. and Wette, R.: The secular trend in diameter of the femur of American Whites and
Negroes. Am. J. Phys. Anthropol., 28: 65-74, 1968.

50) Trouerbach, W.T., Birkenhäger, J.C., Schmitz, P.I.M, . van Hemert, A.M., Saase, J.L.C.M, Collette, H.J.A. and Zwamborn, A.W.: A cross-sectional study of age-related loss of mineral content of phalangeal bone in men and women. Skel. Radiol., 17: 338-343, 1988.

51) Trouerbach, W.T., Grashuis, J.L., Zwamborn, A.W., Clermonts, C.G.M. and Schouten, J.A.: Microdensitometric analysis of bone structure in $\mathrm{X}$-ray images. Skel Radiol., 16: 190-195, 1987.

52) Woodard, H.Q.: The elementary composition of human cortical bone. Health Phys., 8: 513-517, 1962.

\section{Explanation of Figures}

\section{Plate I}

Plate 1. Regression relationships of each variable of the second metacarpal (y) with age (x) in 114 men (solid circles and lines) and 114 women (open circles and dotted lines). Abbreviations of the variables are shown in Table 1. 


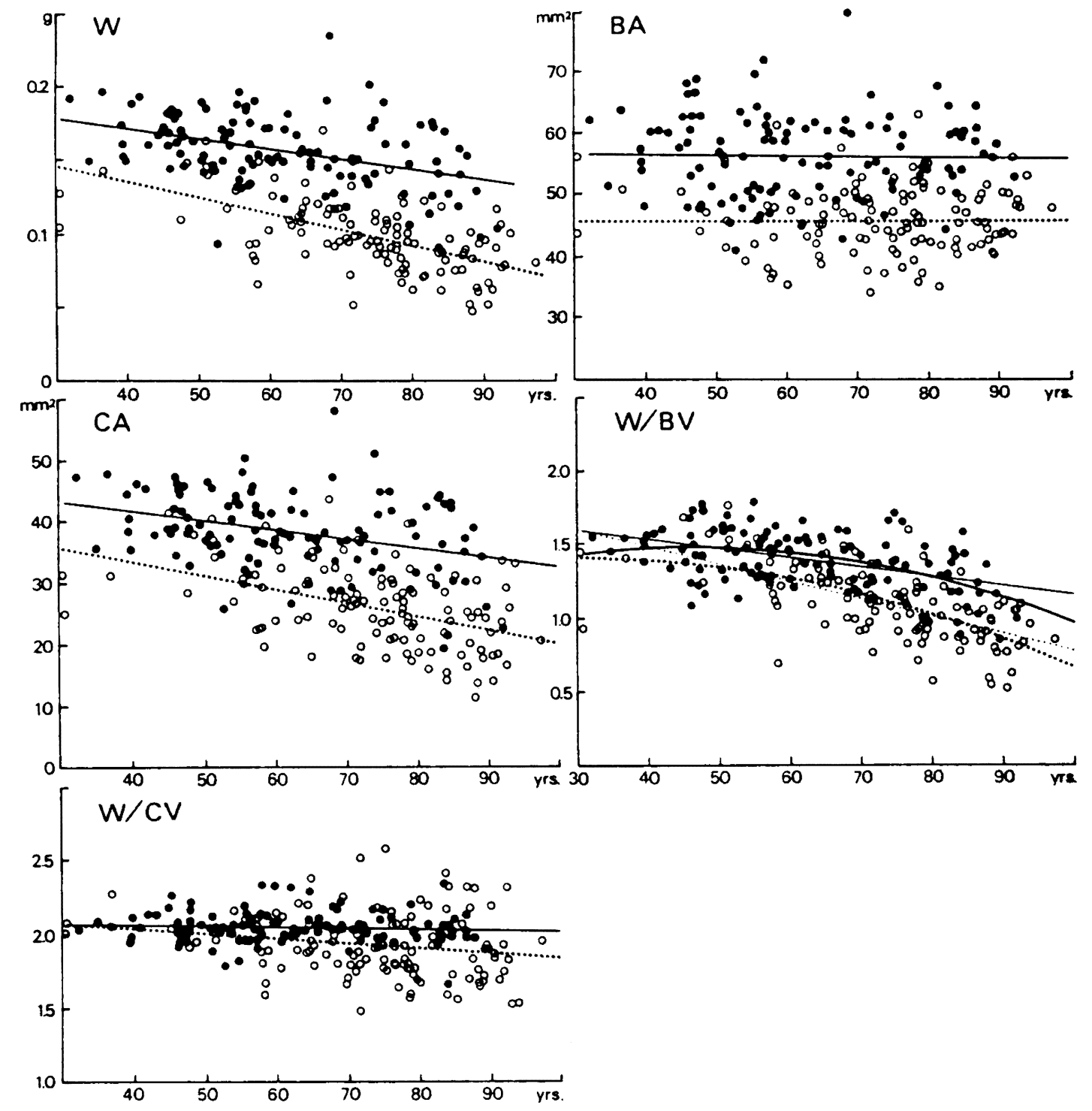

